treating of the genesis of medical thought; a Scottish symposium, which begins with the rise of medical education in Scotland; followed by the medical and scientific exploits of King James IV-it must have been a relief to some of his enforced patients when he was killed at Flodden; Surgeon Apothecaries and Physick Gardens; "Dr. John Brown, 'Rab' and 'Marjorie'," in which tho author gives a reliable account of the youthful genius, Marjory Fleming, whereas Dr. Brown gave rein to his imagination; and "Dr. Francis Adams of Banchory", who combined general practice with Greek scholarship, and refused the professorial chair of Greek in the University of Aberdeen. The next section, "The Geographical Outlook", in addition to the Oslerian Oration, already mentioned, contains an account of "Coryat's Crudities" (published 1608), by an early English traveller, who died "of a flux" at Surat, India, in 1617; "In quest of the witch-doctor", based on the author's African travels; and the Oration to tho Harveian Society of Edinburgh, given in 1956 and entitled "Harvey in Space and Time". Then come a scientific section on "Researches and Discoveries", and a final one, "By-ways in Biography". This last section includes a tercentenary tribute to Religio Medici and Sir Thomas Browne; excellent descriptions of John Hunter, Dr. William Heberden, Laennec and his stethoscope; and two other essays, one on "Modical Dynasties", which, admittedly, omits several notable instances; the other, on "Sherlock Holmes and Medicine", discovers some new aspects in a well-tilled field. Dr. Watson gradually weaned Sherlock Holmes from cocaine. This is very exceptional; but W. S. Halsted, the famous surgeon of Johns Hopkins, also succeeded in overcoming this addiction.

All the essays are well written, full of historical lore, and will appeal to the general reader as well as to the scientist and medical historian.

\section{MAN'S SHARE IN HIS OWN EVOLUTION}

\section{Culture and the Evolution of Man}

Edited by M. F. Ashley Montagu. (Galaxy Book, No. 88.) Pp. xiii + 376. (London and New York: Oxford University Press, 1962.) 18s. 6d.; 2.95 dollars.

$I^{\mathrm{T}}$ is something of an achievement that recent years have returned discussion of the evolution of man's high 'intelligence' to the point where Darwin and Wallace had. it, that is, as something produced by natural selection, following the rather confused views of fifty years ago. But the problem is by no means settlod; at least, it is ono on which, during the past decade, specialists have been able to express a really astonishing diversity of views as to both cause and process.

In the first place, what part of the elephant have we got hold of? In Culture and the Evolution of Man, Dr. Montagu's volume of previously published papers, some authors naturally are content to deal with intelligence or mentality, not further defined; others consider brain (or endocranial) volume as a statistical quantity; and yet others, the whole central nervous system in its capacity as the most general kind of rosponse mechanism. Within such a range the cause (sometimes the pathway) loading to modern man's intellect is suggested to be: the use of external tools as a seloctive force (Washburn); cortical expansion to control emotional behaviour (Chance); general socialization, particularly of the males (Etkin); neoteny, or the retardation of growth and retention of foetal proportions of brain and body (Montagu); re-structuring of personality concomitant with the emergence of culture, with 'intellect' being a function of general personality (Hallowell).
Naturally, these are inadequate tags, but they should serve to show that the subject is not yet overburdened with factual evidence; and the samo evidence can still lead to quite different conclusions, of some importance. Noting the equal brain sizes of Neanderthal and sapiens man, Dobzhansky and Montagu find demonstration in the, stono artefacts of the "existence of minds of a high order of development" in Neanderthal, while Washburn believes the first Homo sapiens to have been a "much more intelligent creature" by comparison.

This collection of articles, some already well known, is a most useful one. Three of the writers are British, the rest American. Not all-only about half-deal primarily with mental evolution, the rest having to do with the nature of culture and its psychobiological prerequisites, or with some specific connexion of culture and biology. Such a one is Livingstone's reconstruction of the spread of the sickling gene in equatorial Africa, as a defenco against malaria, following man's own creation of a malarial environment by clearing the shade forest and creating pools for mosquito-breeding.

Except in his title, the editor does not convey clearly what was in his mind in his introduction or the ordering of the papers, and it is well to begin with Eiseley's reviow essay (though it comes near the end) dealing with ideas on brain evolution reaching back to Darwin and Wallace. However, the range of treatment and view is satisfying and suggestive. Brace has a good article on tho changing role and effect of the dentition in the hominids. Jivingstone deals intensively with the history of one gene, while Dobzhansky and Montagu suggest in the broadest terms how human success came about through a genotype affording great fluidity and plasticity of phenotypical behaviour. Hallowell and Henry provide essays, imaginative but judicious, on the relations of personality and culture as the matrix for solection in brain evolution. Baker and Alice Brues deal with nature, culture and physical form, the former with morphological and physiological responses to climate as mediated by clothing, etc., and the latter with the male body types which would hypothetically be selected by various culture stages or conditions: the running spearman-hunter, the archer, the tiller. (Both fastidiously eschew reference to Sheldon, although the maintenance of marked variety in body-form within modern populations-or families-is a phenomenon still clamouring for attention.)

The closing essay, by Stott, is on the possible selfregulation of the size of a population (for its own Malthusian safety) by the rise of deleterious mutations, and by pre-natal damage to the fotus (or at least evocation of latent genotypic defects) by the stresses on the mother of crowding, harsh living or malnutrition. Much interesting animal and human evidence is cited. "The chief implication of the theory is that the predicted catastrophe of a world population increasing ... to the point of starvation is unlikely to occur."

W. W. Howells

\section{ANTIMICROBIAL AGENTS AND CHEMOTHERAPY}

Die Rohstoffe des Pflanzenreichs

Von Julius von Wiesner. Fünfte Auflage herausgegeben von Constantin von Regel. Lieferung 2: Antibiotiques. Par G. Hagemann. Pp. iii + 272. (Weinheim: Verlag von J. Cramer; Codicote, Herts: Wheldon and Wesley Ltd.; New York: Hafner Publishing Company, 1963.) n.p.

\section{Antibiotica aus Actinomyceten}

Leitfaden für die Isolierung und Charakterisierung. Bearbeitet von V. Sevcík unter Mitarbeit von I. Málek, V. Musílek und Z. Rehácek. Pp. xv +647. (Jena: Veb Gustav Fischer Verlag, 1963.) 70.70 D.M. 